\title{
GAYA KEPEMIMPINAN DEMOKRATIS PERPUSTAKAAN KOTA YOGYAKARTA (STUDI KASUS)
}

\author{
Sri Utari dan Moh. Mustofa Hadi \\ (Universitas Sebelas Maret) dan \\ (Pasca Sarjana UIN Sunan Kalijaga Yogyakarta)
}

\begin{abstract}
The library is a non-profit institution engaged in services and services that are directly related to the community. In order to regulate the rhythm of work continuity, a library organization has a leader, namely the head of the library. The head of the library has a way of leading or often called style, to run a library. Leadership style is the way a leader influences subordinates in running an organization. One type of library is the public library. Sustainability of public libraries will work well requires leaders. Library leaders generally have their own style to carry out their leadership. This research discusses how the leadership style in public libraries? Case study in Yogyakarta City Public Library. The research method used is using literature study, semi-structured interviews, and library observations. The conclusion obtained is that the leadership of the Yogyakarta City Library has a demoratic leadership style. This is evident from every time a decision is made, the head of the library involves staff to submit suggestions and input for the sustainability of the library. These suggestions and input are used as a decision maker. The final result of the decision remains in the hands of the head of the library.
\end{abstract}

Keywords: Public library, leadership style, democratic

\begin{abstract}
ABSTRAK
Perpustakaan merupakan lembaga non profit yang bergerak di bidang jasa dan layanan yang berkaitan langsung dengan masyarakat. Dalam rangka mengatur ritme kerja keberlangsungan sebuah organisasi perpustakaan memiliki seorang pemimpin yaitu kepala perpustakaan. Kepala perpustakaan memiliki suatu cara memimpin atau sering disebut dengan gaya, untuk menjalankan sebuah perpustakaan. Gaya kepemimpinan merupakan cara pemimpin dalam mempengaruhi bawahan dalam menjalan sebuah organisasi.Jenis perpustakaansalah satunyayaituperpustakaanumum. Keberlangsungan perpustakaan umum akan berjalan dengan baik membutuhkan pemimpin. Pemimpin perpustakaan umu memiliki gaya tersendiri untuk menjalankan kepemimpinannya. Penelitian ini membahas tentang bagaimana gaya kepemimpinan di perpustakaan umum? Studi kasus di Perpustakaan Umum Kota Yogyakarta. Metode penelitian yang digunakan yaitu menggunakan kajian pustaka, wawancara semi terstruktur, dan observasi perpustakaan. Kesimpulan yang diperoleh yaitu kepemimpinan Perpustakaan Kota Yogyakarta memiliki gaya kepemimpinan demoratis. Hal ini tampak dari setiap kali dilakukan pengambilan keputusan, kepala perpustakaan melibatkan staf untuk menyampaikan saran dan masukan demi keberlangsungan perpustakaan. Saran dan masukan ini yang dijadikan sebagai salah satu penentu keputusan. Hasil akhir keputusan tetaplah berada di tangan kepala perpustakaan.
\end{abstract}

Kata kunci : Perpustakaan umum, gaya kepemimpinan, demokratis 


\section{PENDAHULUAN}

Organisasi apapun jenisnya dapat berjalan, tidak terlepas dari peran pemimpin. Seorang pemimpin bertugas menjalankan roda organisasi untuk mewujudkan tujuan yang telah ditetapkan. Seorang pemimpin yang baik tidak hanya mengatur dan selalu menyuruh para bawahan, tetapi juga bisa melakukan komunikasi yang baik terhadap bawahan serta menanamkan nilai nilai kepada anak buahnya. Seorang pemimpin tidak mungkin bekerja sendiri tanpa bantuan sebuah tim. Seorang pemimpin memerlukan cara bagaimana menggerakkan anak buah dalam bekerja agar tujuan organisasi dapat terlaksana dengan baik. Cara menggerakan dan memotivasi bawahan oleh setiap pemimpin berbeda beda. Hal ini bisa saja dipengaruhi oleh karakteristik pribadi pemimpin.

Perpustakaan sebagai organisasi yang bergerak di bidang jasa dan layanan sudah tentu memiliki seorang pemimpin. Bidang jasa dan layanan, termasuk perpustakaan perlu memilki seorang pemimpin karena pemimpinlah yang mengatur ritme kerja keberlangsungan sebuah organisasi. Tanpa sentuhan seorang pemimpin mustahil, sebuah organisasi berjalan sebagaimana mestinya. Lazimnya pemimpin perpustakaan seringkali disebut dengan kepala perpustakaan. Kepala perpustakaan memegang penuh segala kebijakan terkait dengan masa depan perpustakaan. Kepala perpustakaanlah yang menentukan kemana organisasi perpustakaan tersebut berjalan. Dalam menjalankan sebuah perpustakaan, seorang pemimpin memerlukan sebuah cara atau gaya dalam mengatur perpustakaan. Cara menjalankan sebuah organisasi perpustakaan, setiap kepala perpustakaan memiliki gaya kepemimpinan yang berbeda-beda. Gaya kepemimpinan dapat dipahami secara sederhana sebuah cara bagaimana pemimpin mengatur dan mempengaruhi bawahan agar bekerja sesuai dengan tujuan yang telah ditetapkan.
Berdasarkan Undang-Undang No. 43 tahun 2007 pasal 20, jenis perpustakaan salah satunya adalah perpustakaan umum.

Perpustakaan umum merupakan "perpustakaan yang diselenggarakan oleh pemerintah, pemerintah provinsi, pemerintah kabupaten/kota, kecamatan, dan desa, serta dapat diselenggarakan oleh masyarakat." (Indonesia, 2007).

Kota Yogyakarta kita kenal sebagi kota pelajar. Sebutan kota pelajar selaras dengan banyaknya perpustakaan yang ada di Kota Yogyakarta, salah satunya yaitu Perpustakaan Kota Yogyakarta. Perkembangan berbagai layanan yang tersedia dan penamaan layanan yang unik-unik di perpustakaan Kota Yogyakarta, tidak lepas dari peran pemimpin perpustakaan tersebut. Oleh karena itu, makalah ini akan membahas tentang gaya kepemimpinan perpustakaan Kota Yogyakarta sehingga dapat mengatur ritme kerja perpustakaan untuk melayani masyarakat umum?

\section{METODE PEMBAHASAN}

Metode pembahasan pada makalah ini adalah dengan menggunakan kajian pustaka, wawancara semi terstruktur, dan observasi perpustakaan. Kajian pustaka diperoleh beberapa sumber buku terkait dengan kepemimpinan organisasi, wawancara semi struktur dilakukan terhadap pustakawan non PNS bagian layanan kritik dan saran dan pustakawan bagian Pusat Data dan Informasi Observasi lapangan dilakukan karena kami ingin melihat secara langsung suasana Perpustakaan Kota Yogyakarta. Observasi dilakukan guna melengkapi metode kajian pustaka dan wawancara semi terstruktur.

\section{LANDASAN TEORI}

\section{Pengertian Pemimpin}

Pemimpin dan kepemimpinan adalah sesuatu yang tak dapat dipisahkan karena merupakan suatu kesatuan. Pemimpin 
hendaknya memiliki jiwa kepemimpinan. Jiwa kepemimpinan terbentuk dari suatu proses dari waktu ke waktu hingga akhirnya akan terbentuk karakteristik kepemimpinan. Pemimpin (leader) pada dasarnya adalah orang yang mampu menggerakkan sumber daya (terutama manusia) untuk bekerja bersama dalam rangka mencapai tujuan. Menurut Jack Welch dalam Anung Pramudyo, pemimpin adalah orang yang memberikan inspirasi dengan visi yang jelas mengenai bagaimana sesuatu dapat dikerjakan dengan cara yang lebih baik. (Pramudyo., 2013)

Menurut Robbert D Stuart bahwa pemimpin adalah seorang yang diharapkan mempunyai kemampuan untuk mempengaruhi, memberi petunjuk dan juga mampu menentukan individu untuk mencapai tujuan organisasi. (Stuart \& Morgan, 2002). Menurut (Spillane, 2006), pemimpin merupakan agen perubahan dengan kegiatan mempengaruhi orangorang lebih daripada pengaruh orang-orang tersebut kepadanya. Dengan demikian dapat dikatakan dalam suatu lembaga baik perusahaan, perkantoran, dan organisasi seperti perpustakaan perlu adanya pemimpin yang baik dan benar gunanya untuk bisa mencapai suatu tujuan bersama dalam kelompok maupun individu. Yang dimaksud pemimpin di perpustakaan adalah kepala perpustakaan.

\section{Pengertian Kepemimpinan}

Kepemimpinan sebagai proses pemimpin menciptakan visi dan melakukan interaksi saling mempengaruhi dengan para pengikutnya untuk merealisasi visi. (Wirawan, 2013). Kepemimpinan merupakan suatu proses mempengaruhi suatu kelompok untuk mencapai tujuan tertentu.(Setyowati, 2013). Kepemimpinan (leadership) mempunyai fokus dalam hal pergerakan yang mencoba membawa sekelompok orang menuju perubahan ke arah yang lebih baik dan ideal. Maka dari itu, dapat dibayangkan bahwa fungsi seorang leader adalah membawa organisasi untuk bergerak. (Lensufiie, 2010)

Kepemimpinan merupakan kemampuan yang dimiliki oleh seseorang untuk mempengaruhi orang lain, agar mereka berbuat sesuatu dalam mencapai suatu tujuan dan maksud. Maksudnya bahwa kepemimpinan setidaknya melibatkan unsur-unsur: orang yang dapat mempengaruhi, orang yang dapat dipengaruhi, dan adanya kegiatan atau serangkaian tindakan tertentu dalam mencapai tujuan organisasi.

Tidaklah mudah menciptakan relasi di dalam kepemimpinan di sebuah organisasi. Perpustakaan secara umum mengandung berbagai konsekuensi dalam setiap lininya, konsekuensi yang dimaksud adalah bahwa setiap lini relasi memiliki suatu konstruksi ideologis di antara aktor yang memainkan perannya, baik secara formal maupun informal. (Laugu, 2015) Konstruksi ideologis ini menjelma dalam bentuk propaganda politis, baik secara terang-terangan maupun secara sembunyisembunyi, dalam mempengaruhi perilaku dan tindakan aktor dalam masyarakat organisasi yang kemudian disebut sebagai representasi kuasa.(Laugu, 2015). Dalam melakukan interaksi, maka pemimpin harus mempunyai kriteria tersendiri. Kumaran menyebutkan bahwa kriteria yang harus dimiliki oleh pemimpin diantaranya adalah pemimpin menetapkan arah dan kecepatan, pemimpin memotivasi, menetapkan tujuan, dan menentukan kebijakan.(Kumaran, 2012)

\section{Gaya Kepemimpinan}

Gaya kepemimpinan merupakan cara pemimpin dalam menggerakkan dan mengarahkan para bawahannya untuk 
melakukan tindakan tindakan yang terarah dalam mendukung pencapaian tujuan. Gaya kepemimpinan pada dasarnya bersifat sementara/ tidak tetap sehingga terkadang sulit dinilai seorang pemimpin menggunakan salah satu dari gaya kepemimpinan yang mana. Faktor yang mempengaruhi gaya kepemimpinan dari seorang pemimpin adalah kepribadian seorang pemimpin itu sendiri.(Raras TS, 2008). Gaya kepemimpinan adalah pola interaksi antara pimpinan dan bawahan. Pola interaksi tersebut membentuk 2 orientasi orientasai perilaku pemimpin terhadap bawahan dan orientasi hubungan antar keduanya.

Jenis gaya kepemimpinan menurut (Tambunan, 2015) yaitu:(a)Kepemimpinan otokratis/ diktatorial (autocratic leadership) merupakan kepemimpinan yang memusatkan kuasa dan pengambilan kepuasan bagi dirinya sendiri. Pemimpin berwenang penuh dan memikul tanggung jawab sepenuhnya. Pemimpin tipe ini tidak suka menerima kritik, saran, pendapat dan pengambilan keputusan dari orang-orang yang di dalam maupun luar organisasi; (b) Kepemimpinan militeristis (militerisme leadership), kepemimpinan ini terlihat pada pemberian perintah dalam menggerakkan para bawahannya. Pemimpin tipe ini terlalu menjaga wibawa dan jabatannya, sehingga pemimpin ini ingin selalu dihormati dam disegani oleh para bawahannya, yang mengakibatkan kekakuan dan kurangnya komunikasi dengan para bawahannya; (c) Kepemimpinan paternalistik (paternalistic leadership). Pemimpin ini menganggap bahwa melalui peran kepemimpinannya akan memberikan harapan kepada para pengikutnya, diharapkan dapat menjadi "bapak" bagi para pengikutnya. Pemimpin ini biasanya merupakan orang yang di-tuakan, dan dihormati, diangkat berdasarkan golongan/kasta, dan/atau berdasarkan keturunan dari seorang pemimpin suku; (d) Kepemimpinan partisipatif (Participatice leadership) merupakan kepemimpinan yang mendesentralisasi wewenang. Ia akan terus melibatkan para anggotanya untuk bekerja bersama-sama dengan pemimpin tersebut. (e) Kepemimpinan Laissez Faire. Gaya kepemimpinan ini umumnya memberi kebebasan penuh untuk membuat keputusan dan menyelesaikan pekerjaan dengan cara apa saja yang dianggap sesuai; (f) Kepemimpinan Bebas-Kendali (freerein leadership). Kepemimpinan yang menghindari kuasa dan tanggung jawab. Pemimpin sebagian besar bergantung pada kelompok untuk menetapkan tujuan dan menanggulangi masalahnya sendiri. Pemimpin hanya memainkan peran kecil serta hanya memikirkan terlebih dahulu akan kebutuhannya sendiri. Jenis kepemimpinan ini kurang efektif dalam menjalankan organisasi yang menghadapi persaingan. (g) Kepemimpinan karismatis (charismatic leadership). kharismatis diasumsikan sebagai suatu karakteristik individual dari pemimpin. Karisma adalah bentuk daya tarik interpersonal untuk memperoleh dukungan dan penerimaan; (h) Kepemimpinan demkoratis (democratic leadership) merupakan pemimpin yang cenderung melibatkan karyawan dalam mengambil keputusan, mendelegasikan wewenang, mendorong partisipasi dalam memutuskan metode dan sasaran kerja, dan menggunakan umpan balik sebagai peluang untuk melatih karyawan. Pemimpin tersebut berupaya untuk mengajari dan mengembangkan daya inovasi dan kreatifitas dari para bawahannya.

\section{Kepemimpinan Demokratik}

Kepemimpinan demokratis adalah kepemimpinan yang berfokus pada dasar kemanusiaan dan menjunjung 
tinggi derajad dan harkat manusia yang dipimpinnya. (Suradji \& Martono, 2014)

Ciri-ciripemimpin demokratis Menurut Siagian adalah Dalam proses pergerakan bawahan selalu bertitik tolak dari pendapat bahwa manusia makluk termulia, selalu merusaha mensinkronisasikan kepentingan dan tujuan organisasi dengan kepentingan dan tujuan pribadi bawahan, senang menerima saran/ pendapat/ kritik dari bawahan, mengutamakan kerjasama, menjadikan bawahan lebih sukses dari padanya, berusaha mengembangkan kapasitas diri pribadi. (Suradji \& Martono, 2014)

Tipe perilaku pemimpin demokratis menurut pendapat Gouzali Syadan antara lain: mengutamakan kerja antara atasan dan para bawahan, memberi kesempatan kepada bawahan untuk maju dan mengembangkan diri, membangun semangat dan gairah kerja bawahan, menganggap bawahan sebagai rekan kerja, tidak segan-segan membina bawahan dan menstransfer ilmu kepada bawaha. (Suradji \& Martono, 2014)

\section{Hakikat Kepemimpinan Perpustakaan}

Pada hakikatnya kepemimpinan terletak pada kemampuan seorang pemimpin mengajak dan mempengaruhi pihak lain termasuk bawahan, untuk bekerja bersama untuk melakukan kegiatan tertentu dalam rangka merealisasi tujuan utama secara efektif dan efisien dalam suasana kerja yang menyenangkan. Oleh karena itu kepemimpinan dalam hal ini kepemimpinan perpustakaan harus bisa memberikan arahan dan motivasi kepada bawahan agar menjalankan tugas dan fungsi perpustakaan dengan baik.

Tidak kalah penting dalam pengembangan perpustakaan adalah peran kepala perpustakaan dalam mengembangkan sumber daya manusianya. Tidak semua kepala memiliki pandangan yang sama dalam kaitannya dengan pengembangan sumber daya manusia. Sangat baik apabila kepala perpustakaan memberikan kesempatan kepada para pegawai untuk berkembang baik melalui pendidikan formal maupun pelatihanpelatihan. Dan akan sangat baik apabila kepala perpustakaan tidak khawatir bahwa pendidikan atau kepangkatannya disamai oleh pegawainya di dalam perpustakaan. Mengirimkan pegawai untuk mengikuti pendidikan dan pelatihan bagi yang mampu sangat besar artinya bagi perkembangan perpustakaan. Kepala yang takut persamaan strata pendidikan ataupun kepangkatannya akan selalu berusaha membuat pengembangan pegawainya terhambat.

Dalam konteks hakikat kepemimpinan perpustakaan, ditawarkan konsep leadership yang bertujuan guna membantu menentukan pemimpin yang kredibel dan profesional. Konsep kepemimpinan perpustakaan menurut (Ridwansyah, 2012) meliputi: (a) Aspek physicality dimana kemampuan seorang pemimpin dilihat dari hal-hal fisik pada diri pemimpin merupakan aspek awal yang dilihat dari seorang pemimpin.Seorang pemimpin yang memenuhi aspek tersebut adalah pemimpin yang sering menebarkan senyum, berpakaian rapi, berjalan tegak dan selalu menyapa setiap orang; (b) Aspek intellectuality dimana kemampuan seorang yang menekankan pada kecerdasan yang dimiliki pemimpin. Dimana seorang kepala perpustakaan harus cerdas dalam menemukan dan mengeksekusi peluang yang ada. Kecerdasan seorang pemimpin harus memberikan dampak positif bagi semua yang ada di perpustakaan; (c) Aspek emotionality, seorang pemimpin harus terkontrol dengan baik dalam upaya mempertahankan citra positif seorang 
pemimpin dimata pegawai perpustakaan. Kepala perpustakaan perlu memiliki dan mempelajari manajemen emosi agar tekanan yang dihadapi tidak mempengaruhi kondisi psikologis/psikisnya; (d) Aspek sociability, seorang pemimpin harus memiliki jiwa sosial yang tinggi. Diman kepala perpustakaan harus mempunyai respon sosial yang tinggi terhadap masyarakat yang ada di sekitar perpustakaa. Kemampuan ini akan dengan sendirinya membawa pengaruh besar terhadap perpustakaan. Misal Kepala perpustakaan mengikuti kegiatan sosial sehingga menjadi manuver untuk mengajak masyarakt untuk datang ke perpustakaan. Artinya membangun jaringan sosial sebagai modal untuk meluaskan pengaruh yang dimilik oleh pemimpin; (e) Aspek personability merupakan aspek dari kepemimpinan yang berkaitan dengan kesadaran tentang hakikat diri serta visi-misi perpustakaan yang akan dijalankan, diperjuangkan dan disebarluaskan kepada bawahan; (f) Aspek morability, dimana kepala perpustakaan harus menjadi contoh bagi bawahan terkait dengan aspek moralitas, kepribadian, dan motivasi. Dengan kata lain hal ini menjadi pondasi kepemimpinan yang paling penting karena berkaitan dengan kesadaran kemampuan untuk menjaga integritas moral untuk dapat memberikan pengaruh kepada orang lain secara lebih berkelanjutan dan berjangka panjang

\section{HASIL DAN PEMBAHASAN}

\section{Kepemimpinan Perpustakaan Kota Yogyakarta}

Berdasarkan hasil wawancara dengan pustakawan di Perpustakaan Kota Yogyakarta, menyebutkan secara langsung bahwa gaya kepemimpinan Perpustakaan Kota Yogyakarta yaitu kepemimpinan demokratis. Hal ini juga didukung dengan keterangan bahwa tindakan yang dilakukan oleh pemimpin perpustakaan melibatkan staf pustakawan dan non pustakawan dalam pengambilan keputusan. Secara rutin dijadwalkan agenda untuk rapat koordinasi yaitu satu minggu sekali setelah apel pagi yang dilaksanakan setiap hari senin kemudian dilanjutkan dengan rapat koordinasi membahas program kerja dan permasalahan yang terjadi di pelayanan. Kepala Perpustakaan Kota Yogyakarta sepertinya memahami betul bahwa dengan melibatkan staf dalam pengambilan keputusan agar terjalin komunikasi yang baik sehingga jarak antara atasan dan bawahan tidak terlalu jauh. Komunikasi yang baik akan menjadikan sebuah organisasi dalam hal ini perpustakaan kota yogyakarta berjalan optimal.

Struktur organisasi di Perpustakaan Kota disusun secara berjenjang dari kepala, kepala bidang, kepala seksi dan koordinator bidang. Penyelesaian masalah dilakukan secara berjenjang, apabila pimpinan terendah sudah dapat menyelesaikan masalah maka langsung ditangani, apabila belum dapat baru diajukan ke pimpinan yang lebih tinggi. Hal ini dikarenakan untuk mempercepat dalam menangani masalah yang terjadi.

\section{Kepemimpinan}

Demokratis Perpustakaan Umum Kota Yogyakarta

Kepemimpinan demokratis cenderung melibatkan bawahan dalam pengambilan keputusan,mendelegasikan kekuasaan, mendorong partisipasi bawahan dalam pencapaian tujuan.(Rivai, 2004). Guna menggambarkan kepemimpinan demokratis Perpustakaan Kota Yogyakarta, penulis meminjam pendapat Sutarto, ciri kepemimpinan demokratis menurut (Sutarto, 1989) adalah : 
a. Dimensi Keputusan

Keputusan dibuat bersama dengan bawahan. Kepala perpustakaan kota yogyakarta sering melibatkan bawahan dalam memutuskan segala kebijakan terkait dengan hal hal penting perpustakaan kota yogyakarta. Esensi kepemimpinan demokratis adalah bahwa segala keputusan seringkala mempertimbangkan dan atau melibatkan bawahan sebagai bahan pertimbangan. Namun pada akhirnya keputusan akhir di tangan pimpinan dalam hal ini kepala perpustakaan.

b. Dimensi Wewenang

Ciri pemimpin demokratis adalah bahwa Pemimpin bersedia untuk melimpahkan sebagian wewenangnya kepada orang lain. Kepala perpustakaan kota yogyakarta tidak segan memberikan wewenang kepada wakil atau kepada staf yang ditunjuk untuk memimpin rapat ketika kepala perpustakaan berhalangan hadir.

c. Dimensi Komunikasi

Komunikasi berlangsung timbal balik. Komunikasi antara pimpinan dan bawahan berjalan dengan baik, sehingga semua informasi kerja diketahui semua komponen yang terkait.

d. Dimensi Pengawasan

Pemimpin melakukan pengawasan secara wajar terhadap sikap, tingkah laku dan perbuatan atau kegiatan bawahan. Pemimpin menerima saran dari bawahan. Gaya kepemimpinan demokrasi tidak antikritik, kepemimpinan demokrasi senantiasa dalam bekerja selalu menerima saran dari bawahan.

e. Dimensi Kritik dan Saran

Kritik dan saran Pemimpin memberikan pujian dan kritik yang seimbang. Pemimpin memberikan pujian kepada bawahan yang bekerja dengan baik, tetapi memberi kritik yang membangun untuk meningkatkan semangat bawahan dalam bekerja. Kepala perpustakaan banyak memberi kesempatan kepada bawahan untuk memberikan saran, pertimbangan dan pendapat dalam menyelesaikan pekerjaan. Kepala perpustakaan senantiasa menerima kritik dan saran baik dari staf maupun dari masyarakat. Kritik dan saran tersebut dapat disampaikan secara langsung. Biasanya saran dari staf kepada kepala perpustakaan disampaikan secara lisan saat kegiatan apel senen pagi.

f. Dimensi Motivasi Kerja

Motivasi perlu diberikan dari seorang pemimpin terhadap staf/ bawahan. Motivasi ini penting mengingat, dengan motivasi inilah akan memacu semangat kerja seorang bawahan dalam menjalankan aktivitas organisasi dalam hal ini perpustakaan. Adapun motivasi kepala perpustakaan kota yogyakarta sebagaimana hasil wawancara yang kami lakukan adalah sebagai berikut: "Beliau seringkali memberikan motivasi kepada para pustakawan dan non pustakawan dalam bekerjaagarsenantiasamengedepankan mutu layanan perpustakaan dengan baik." Penyelesaian tugas. Pimpinan mendorong bawahan untuk menyelesaikan tugas dengan sempurna dalam batas kemampuan yang wajar. Pimpinan tidak memaksakan bawahan untuk bekerja melampaui kemampuan bawahan.

g. Dimensi Kepemimpinan

Kepemimpinan kepala perpustakaan di Perpustakaan Kota Yogyakarta berada dibawah 
dan bertanggung jawab langsung kepada walikota yogyakarta, kepala perpustakaan Perpustakaan Kota Yogyakarta juga mempunyai tanggung jawab melaporkan segala rencana kerja. Hal ini tampak dari jawaban yang diutarakan oleh staf perpustakaan bahwa "Bapak Wahyu Hendratmo adalah nama kepala perpustakaan kota yogyakarta, Kepala Perpustakaan Kota Yogyakarta dipilih oleh Bapak Walikota Yogyakarta. Karena Perpustakaan kota yogyakarta dibawah koordinasi Pemerintah Kota Yogyakarta"

h. Dimensi Latar belakang pendidikan

Pendidikan kepala perpustakaan kota yogyakarta bukan berasal dari jurusan ilmu perpustakaan lazimnya sebuah kepala perpustakaan. Kepala perpustakaan berpendidikan manajamen ekonomi. Hal ini kami peroleh dari hasil wawancara yang kuranglebih"Latarbelakangpendidikan beliau adalah Manajemen Ekonomi. Walaupun tidak berlakang belakang pendidikan ilmu perpustakaan, beliau mumpumi memimpin Perpustakaan Kota Yogyakarta selama ini.

\section{KESIMPULAN}

Pada dasarnya pemimpin harus bisa memberikan contoh kepada yang dipimpin agar dapat melakukan sesuai dengan arahan pimpinan. Bagaimanapun juga kepala perpustakaan memegang peranan yang penting dalam keberlangsungan sebuah perpustakaan. Tanpa seorang kepala perpustakaan dalam hal ini pemimpin perpustakaan, jalan perpustakaan akan mengalami kendala. Kepala perpustakaan ibarat kapal mengarungi ombak lautan, kepala perpustakaan berperan sebagai nahkoda yang menentukan arah dan tujuan kapal dalam hal ini organisasi perpustakaan. Menjalankan sebuah organisasi diperlukan cara dalam menjaga keberlangsungan organisasi. Tanpa cara, sudah pasti sebuah organisasi tidak akan bisa berjalan. cara inilah yang disebut dengan gaya.

Gaya kepemimpinan Perpustakaan Kota Yogyakarta adalah gaya kepemimpinan demokratis. Hal ini tampak dari setiap kali dilakukan pengambilan keputusan, kepala perpustakaan seringkali melibatkan dan atau meminta saran dari bawahan agar kebijakan yang diambil bisa berjalan dengan baik. Saran dan masukan ini yang dijadikan sebagai salah satu penentu keputusan. Hasil akhir keputusan tetaplah berada di tangan kepala perpustakaan. Dengan demikian kepemimpinan perpustakaan kota yogyakarta adalah memiliki gaya kepemimpinan demokratis.

\section{DAFTAR PUSTAKA}

Indonesia. Undang-Undang Nomor 43 tentang perpustakaan., (2007).

Kumaran, M. (2012). Leadership in Libraries: a Focus on Ethnic-Minority Libraries. United Kingdom: Chandos Publishing.

Laugu, N. (2015). Representasi kuasa dalam pengelolaan perpustakaan. Yogyakarta: : Gapernus Press.

Lensufie, T. (2010). Leadership Untuk Professional dan Mahasiswa. Jakarta: Erlangga.

Pramudyo., A. (2013). Implementasi Manajemen Kepemimpinan dalam Pencapaian Tujuan Organisasi. JBMA, 1(2), 50 .

Raras TS, A. (2008). Menjadi Manager Sukses : Melalui Empat Aspek Perusahaan. (Bandung: Alfabeta.

Ridwansyah, A. (2012). Leadership 3.0: Seni Kepemimpinan Horizontal untuk Semua Orang. Jakarta: Markplus Institute.

Rivai, V. (2004). Manajemen sumber daya manusia untuk perusahaan. Jakarta: PT. Raja Grafindo Persada. 
Setyowati. (2013). Organisasi dan Kepemimpinan Modern. (Yogyakarta: Graha Ilmu.

Spillane, J. p. (2006). Distributed leadership. San Francisco: Jossey Bass.

Stuart, R. D., \& Morgan, B. B. (2002). Library and Information Centre Management. USA: Library Unlimited.

Suradji, G., \& Martono, E. (2014). Ilmu dan Seni Kepemimpinan. (Bandung: Pustaka Reka Cipta.

Sutarto. (1989). Dasar-dasar Kepemimpinan Administrasi. (Yogyakarta: Gadjah Mada University Press.

Tambunan, T. S. (2015). Pemimpin dan Kepemimpinan. Yogyakarta: Graha Ilmu.

Wirawan. (2013). Kepemimpinan: Teori, Psikologi, Perilaku Organisasi, Aplikasi dan Penelitian. Jakarta: Rajawali Pers. 